\title{
Aesthetics and Tourism
}

\author{
Margarita Barretto*
}

Universidade Federal de Santa Catarina

\begin{abstract}
The aim of this few comments is to link tourism to the desire for beauty that seems to be side by side with humankind since the very beginnings. Reflections are grounded on Benjamin's interpretation of Baudelaire, on Boorstin, MacCannel and Urry, as well as on my own field experience and intend to stimulate more research on the role played by aesthetics in tourism experience.
\end{abstract}

Key words: Image destination; Aesthetics and Tourism.

\section{A brief starting point}

Why tourist destinations are sold as "paradises"?; Why some resorts in poor places of the third world encapsulate their guest to prevent them from the sight of slums?; Why gentrified or refurbished neighborhoods or harbors have such an appeal not only as tourist attractions but as spaces of leisure. Scape seems to be the answer. Beauty matters for everybody since humankind exists.

On the wish for beauty (aesthetical approach)

Paleontologists and archeologists have found evidences of a sense of beauty in pre-historic communities, in handicrafts, paintings and also burial places where vestiges of flowers were detected. Greek and roman wall paintings and engravings testify ancient cultures enjoyed wearing several kind of ornaments. Egyptian Nefertiti's necklaces and Tutankhamen treasures, or Cleopatra's pearls in western culture; colorful feathers in America and Africa. Let alone Chinese porcelain which demanded long years of research for Europeans to find the formula and industrialize. Why would they be so interested in? A flowerpots is a flowerpot.... why should people want to have a china one? Because Chinese porcelain is beautiful, each piece a work of art.
A survey on tourism magazines accounts for endless appeals to enjoy paradise, displaying photos of blue seas, green islands, sailing boats, palm trees, splendorous sunsets. Also urban tourism is sold with images of beauty; impressive cityscapes inviting to be walked, beautifully dressed people, gorgeous show cases, glittering spot lights, cozy restaurants.

Everywhere in tourism or leisure folders beautiful dishes are presented. A meal should be a meal, but faced to different options people would take the most beautifully arranged, regardless of the taste. ...That's what "eating with the eyes" is about ... selecting food according to an aesthetic judgment.

Tourists' quest is for beauty. Aesthetics matters. The way rooms are decorated, the uniform staff wares at hotels and planes, the way the girl's hair is dressed, their makeup. Sometimes even wearing glasses could be a reason not to be admitted as a clerk just to fit the expectations of tourists seeking for a perfect world, a kind of Tomas Morus island of Utopia where everybody is happy and perfect, never overweight... Films and TV episodic shows as Fantasy Island could be labeled as emblematic of that desire of reaching paradise by plane...

Assuming tourists are in search of beauty, it is easy to understand why in tourism folders

* Professor at Fundação Universidade Regional de Blumenau, Brasil. Researcher at CNPq - Conselho Nacional de Pesquisa, Brasil. Visiting Professor at UFSC- Universidade Federal de Santa Catarina 
there are no images of garbage, floods, burglary or poverty; no homeless depicted as well as devastated forest or polluted bays and dying fishes in the sand.

Some fifty years ago United States American historian Daniel Boorstin triggered a neverending discussion on the way tourism had overcome the true experience of travel, and tourist consumed pseudo-events. Pseudo-events was a concept he created to mean synthetic novelties tailored to fit consumers' expectations, be those consumers tourists or not. From the 1960 decade on, he says, the main concern is to build images, not only because they sell, but because it "is what people wants to buy" (Boorstin, 1992:204). Tourists travel to a foreign country, he says, to check whether their impressions on the Trevi Fountain or of Hong Kong matches their portrayal in movies (Boorstin, 2992:116). I don't intend to argue about that statement, because there is no single tourist, there are tourists in plural so some of them may enjoy pseudoevents, others may not. What I really want to append is that tourists enjoy aesthetics in any event, staged or not, and the buy beautiful images, not any.

Following the former's thoughts, even in discordance with most assertions about tourists desires, anthropologist Dean McCannel reinforced this vision of tourism as a kind of spurious experience, where people were offered a staged authenticity. Supported by Gofmann's theory of front and back regions, MacCannel (1967:102) considered that back regions were decorated, sometimes "cosmetically decorated" to create a kind of atmosphere to make the place look authentic or suitable. The question is, why should back regions need decoration? Aesthetics is the obvious answer. Any reader would agree that to visit a messy kitchen in the restaurant is very different from visiting e neat one.

In tourism market, the first thing costumers make contact with is the image of the place they will visit. A collection of images of beauty, peace and neatness selected and photo shopped by marketing and advertising ${ }^{1}$. Once arrived to tourism destinations or tourism attractions, those who want to see the back stages have an anticipated idea of what they want to see. And they don't expect dirt or lack of order, they expect the aesthetics they have foreseen.

Like people, tourist attractions or facilities, cityscapes and landscapes, are appreciated if properly dressed and perfumed.

As Baudelaire remarked in XIX century, and Benjamin analyzing his poems about 1930, the beauty of the arcades in Paris gave birth to fla- nerie. The flaneur came to be, when the streets became clean and peaceful, when the images of what a city should be became real.

The will of strolling around seems to be the only thing that has not changed in tourism since its very beginnings three centuries ago, or even before. On march the 5th 1787 Wolfgang Goethe wrote about Naples:

I can't begin to tell you of the glory of a night by full moon when we strolled through the streets and squares to the endless promenade of the Chiaia, and then walked up and down the seashore. I was quite overwhelmed by a feeling of infinite space. (Goethe, 1970:191)

Later in Paris the arcades (glass covered street pathways) should offer the flaneur's eyes the possibility of transforming the city in scape. He would be at ease experiencing the new rhythm of crowded cities and passing by elegant shops cases just for the aesthetic experience of watching ${ }^{2}$.

By the end of the XXth century Urry would also state that tourism consumption is image oriented, it is visual consumption, and that tourists look forward sight-seeing, either natural landscapes or cityscapes. Sights that make them sigh..... Of course tourists are not all the same; the generic tourist does not exist; some tourists do like morbid experiences as visiting war places but we can argue that is an aesthetic option $t^{3}{ }^{3}$. The consumption of places is increasingly aestheticized and less functional, Urry sentences (1995:151).

Few intellectual tourists would care -or even be aware- if poor dwellers are hidden out by walls at a tourism resort in a Caribbean island. And not because tourists are insensitive or evil people, but because, on the contrary, they do care, and the sight of harsh living conditions, the smell of garbage or sewage, hurts. As well as a fallen tree, an abandoned train, ship wreckage, or an ancient house turning into debris.

Tourist places are meant to be sites of pleasure (Urry, 1990: 125), that's why gentrified neighborhoods and harbors have had such an outstanding success from the 1960's on.

A recent field research conducted by myself with Master candidates in Architecture in a refurbished street downtown Florianopolis (Brazil) had as an outcome that one of the most important motives to like gentrified neighborhoods is just walking around. No car permitted or restrictive traffic rules offer safety; law enforcement offers security, and inhibits the typical harassment in third world public places due to social inequalities. But what interviewees reported to like best is the surrounding beauty. 
Surprising as it may seem, most store owners were not worried about more earnings or profits; they were just proud the street they are settled in had turned into a such beautiful place. As for pedestrians, large and neat sidewalks, clean roofs which protect from rain and sun but also embellish, elegant and colorful showcases, comfortable benches, fragrant flower pots, restored old buildings with glorious facades, sometimes calm music, make the difference.

Like baudelairian flaneurs, post-modern citizens as well as tourists love "hanging around" enjoying every sensation, every aesthetic experience that places them into the image of paradise they have idealized for their pleasure trip or leisure moments.

I hope these few comments above may trigger further research on the role beauty and aesthetics play in tourism consumption and tourists choices.

\section{References}

Benjamin, Walter

1985 Charles Baudelaire: A lyric poet in the era of high capitalism. London: Verso. First ed. 1976

Boorstin, Daniel

1992 The Image. A guide to pseudo-events in America. New York: Vintage Books.

Goethe, J. Wolfgang

1970 An Italian journey. London: Penguin Books. Penguin classics col.

MacCannel, Dean

1999 The tourist. A new theory of the leisure class. Berlekely: University of California Press.

Urry, John

1990 The tourist gaze. Leisure and Travel in contemporary societies. London: Sage

Urry, John

1995 Consuming places. London: Routledge

\section{Notas}

1 Correspondence between images and experience will not be analyzed here.

2 Which came to an and with department stores (Benjamin, 1985

3 The focus here is on leisured tourists. Cultural tourism may trigger another kind of argument.
Recibido:

$18 / 04 / 2012$

Reenviado:

$20 / 05 / 2013$

Aceptado:

$01 / 07 / 2013$

Sometido a evaluación por pares anónimos 